\title{
Mangrove Resources, Human Disturbance and Rehabilita- tion Action in China
}

\author{
FAN HANGQING \\ Guangxi Mangrove Research Center, Beihai, Guangxi 536000 \\ (Received August 9, 1994)
}

\section{Introduction}

Mangrove forests in China did not receive much attention in the world because it is small in scale in comparison with the mangroves in the Southeast and East Asian countries, and was little known by oversea scientists. Even though mangroves have been widely used since the ancient time by the local Chinese people as timber, firewood, tannin, food, medicine, green manure and fisherine site, only about fourteen years ago did the government really start to realize the importance of mangroves in maintaining the coastal economic development. Since then, more and more programs pertaining to the conservation, plantation and research of the mangroves have been supported. However, when the conservation programs conflict with exploitation, some of the local government agencies and people tend to put their interests in economy, so the human distur-s bance of mangrove system is still serious, and social management is urgently needed today. This paper is a brief mangrove country report with the focus on current status of mangrove resources, the influences of human activity on mangroves, and some rehabilitation actions being performed in China.

\section{Mangroves}

Mangroves only occur along the coast of Southeastern China where the climate is subtropical or tropical. From south to north, mangroves distribute in the provinces of Hainan, Guangxi, Guangdong, Fujian, Taiwan and Zhejiang (Figure 1) with a total species number of 26 for mangrove plants and 11 for semi-mangrove plants (Table 1). Semi-mangrove plants are defined as woody plants with amphibious characteristics, i. e. they can occur both in sea water and on land where they are occasionally flooded by highest tides.

It is very difficult to exactly estimate the area of pristine mangrove forests in China. Even though the present data were investigated at different time with varied methods by different authors, it is a fact that mangroves were severely degraded from the 1950 s to 1970 s. For example, in the 1950 s there were 10 000ha mangroves surrounding Hainan Island (Chen et al. , 1986), but only 4836ha remained by the end of 1985 (Lin et al. , 1985). In Fujian province 719 ha forests existed in the 1960 s (Lin et al. , 1981), but no 
more than 250ha are now still standing (Fan; 1990). In Guangxi province, there were more than 12246 ha mangroves, but only 5654 ha of them are left at the present (Fan, 1993). It is believed that the mangrove area in China keeps decreasing, thus the real area now is no more than 14853 ha (Table 2).

Table 1 Distribution of mangrove and semi-mangrove species in China (Lin, 1993).

\begin{tabular}{|c|c|c|c|c|c|c|c|}
\hline \multirow{2}{*}{ Family } & \multirow{2}{*}{ Species } & \multicolumn{6}{|c|}{ Province ${ }^{a)}$} \\
\hline & & (1) & (2) & (3) & (4) & (5) & (6) \\
\hline \multicolumn{8}{|l|}{ Mangrove } \\
\hline \multirow[t]{8}{*}{ 1. Rhizophoraceae } & 1. Bruguiera cylindrica & + & & & & & \\
\hline & 2. B. gymnorrhiza & + & + & + & + & + & \\
\hline & 3. B. sexangula & + & & & & & \\
\hline & 4. B. s. var. rhynochopetala & + & & & & & \\
\hline & 5. Ceriops tagal & + & + & + & + & & \\
\hline & 6. Kandelia candel & + & + & + & + & + & + \\
\hline & 7. Rhizophora apiculata & + & & & & & \\
\hline & $\begin{array}{l}\text { 8. R. stylosa } \\
\text { 9. R. mucronata }\end{array}$ & + & + & + & + & & \\
\hline \multirow[t]{2}{*}{ 2. Acanthaceae } & 10. Acanthus ebractearas & + & + & & & & \\
\hline & $\begin{array}{l}\text { 11. A. ilicifolius } \\
\text { 12. A. xiamenensis }\end{array}$ & + & + & + & + & $\begin{array}{l}+ \\
+\end{array}$ & \\
\hline 3. Barringtoniaceae & 13. Barringtonis racemosa & + & & & & & \\
\hline \multirow[t]{2}{*}{ 4. Combretaceae } & 14. Lumnitzera littorea & + & & & & & \\
\hline & 15. L. racemosa & + & + & + & + & & \\
\hline 5. Euphorbiaceae & 16. Excoecaria agallocha & + & + & + & + & + & \\
\hline 6. Meliaceae & 17. Xylocarpus granatum & + & & & & & \\
\hline 7. Myrsinaceae & 18. Aegiceras corniculatum & + & + & + & + & + & \\
\hline 8. Palmae & 19. Nypa fruticans & + & & & & & \\
\hline 9. Rubiaceae & 20. Scyphiphora hydrophyllacea & + & & & & & c. \\
\hline 10. Sonneratiaceae & 21. Sonneratia alba & + & & & & & \\
\hline & 22. S. caseolaris & + & & & & & \\
\hline & 23. S. hainanensis & + & & & & & \\
\hline & 24. S. ovata & + & & & & & \\
\hline 11. Sterculiaceae & 25. Heritiera littoralis & + & & + & & & \\
\hline \multirow[t]{2}{*}{ 12. Verbenaceae } & 26. Avicennia marina & + & + & + & + & + & \\
\hline & subtotal & 24 & 10 & 10 & 9 & 7 & 1 \\
\hline \multicolumn{8}{|l|}{ Semi-mangrove } \\
\hline \multirow[t]{2}{*}{ 1. Acrostichaceae } & 1. Acrostichum aureurm & + & + & + & + & + & \\
\hline & 2. A. speciosum & + & + & & & & \\
\hline 2. Apocynaceae & 3. Cerbera manghas & + & & + & + & & \\
\hline 3. Bignoniaceae & 4. Dolichandron spathacea & + & + & & & & \\
\hline 4. Compositae & 5. Pluchea indica & + & + & & + & & \\
\hline 5. Hernandiaceae & 6. Hernandia sonora & + & & & & & \\
\hline 6. Leguminosae & 7. Pongamia pinnata & + & + & + & + & & \\
\hline 7. Lythăceae & 8. Pemphis acidula & + & & & + & & \\
\hline 8. Malvaceae & 9. Hibiscus tiliscus & + & + & + & + & + & \\
\hline & 10. Thespesia populnea & + & + & + & + & & \\
\hline 9. Verbenaceae & 11Premna obtusifolia & + & + & + & + & & \\
\hline$\therefore$ & subtotal & 11 & 8 & 6 & 8 & 2 & \\
\hline
\end{tabular}

a) (1)Hainan, (2)Guangdong, (3)Guangxi, (4)Taiwan, (5)Fujian, (3)Zhejiang 
Table 2 The mangrove area in southeastern China.

\begin{tabular}{l|l|l}
\hline Province & Area (ha) & Reference \\
\hline Hainan & 4836 & Lin and Lu 1985 \\
\hline Guangxi & 5654 & Fan 1993 \\
\hline Guangdong & 3813 & Su 1989 \\
\hline Fujian & 250 & Lin and Fan 1992 \\
\hline Taiwan & 300 & Fan 1993 \\
\hline Zhejiang & a few & Fan 1990 \\
\hline Total & 14853 & \\
\hline
\end{tabular}

\section{Human disturbance}

The major causes, including direct and indirect, of mangrove degradation are summarized in Table 3. In China, a great part of disappeared mangroves were resulted from building seabund, and the reclaimed mangrove area was converted to agriculture and salt production. It is reasonable to believe that more than two third of the original mangroves in China were depleted on these purposes. These kinds of degradation mainly took place during the period from the later 1950s to the early 1970s. For instance, in Guangxi province there are now $5683 \mathrm{ha}$ salt land, and at least 10 000ha reclaimed farm land, about $80 \%$ of the lands used to be mangrove swamps. With the development of coastal economy, the reclamation practices do not stop basically, not for agriculture and salt production, but for construction of shrimp pond, city settlement, harbour and industry. It can be estimated that more than 1000 ha mangroves are right now under the cutting danger.

Table 3 The change tendency of human disturbance to mangrove forest in China.

\begin{tabular}{l|l|l|l}
\hline Disturbance & Past & Present & Future \\
\hline Direct & & & \\
Building seabund & +++ & ++ & + \\
Salt production & +++ & ++ & + \\
Agricultural itind & +++ & ++ & + \\
Shrimp pond & + & ++ & +++ \\
City settlement & + & ++ & +++ \\
Harbour construction & + & ++ & +++ \\
Industrial land & + & ++ & +++ \\
Repair of seabund & ++ & ++ & ++ \\
Timber & +++ & ++ & + \\
Firewood & +++ & ++ & + \\
Green manure & +++ & ++ & ++ \\
Plant Food & ++ & ++ & +++ \\
Animal Food & ++ & ++ & ++ \\
Feed & +++ & +++ & ++ \\
Medicine & + & + & +++ \\
Indirect & & ++ & ++ \\
Pollution & + & ++ & ++ \\
Tourism & + & ++ & + \\
Land soil loss & + & & + \\
\hline
\end{tabular}

Note: Damage degree: Heavy +++ , medial ++ , light + 


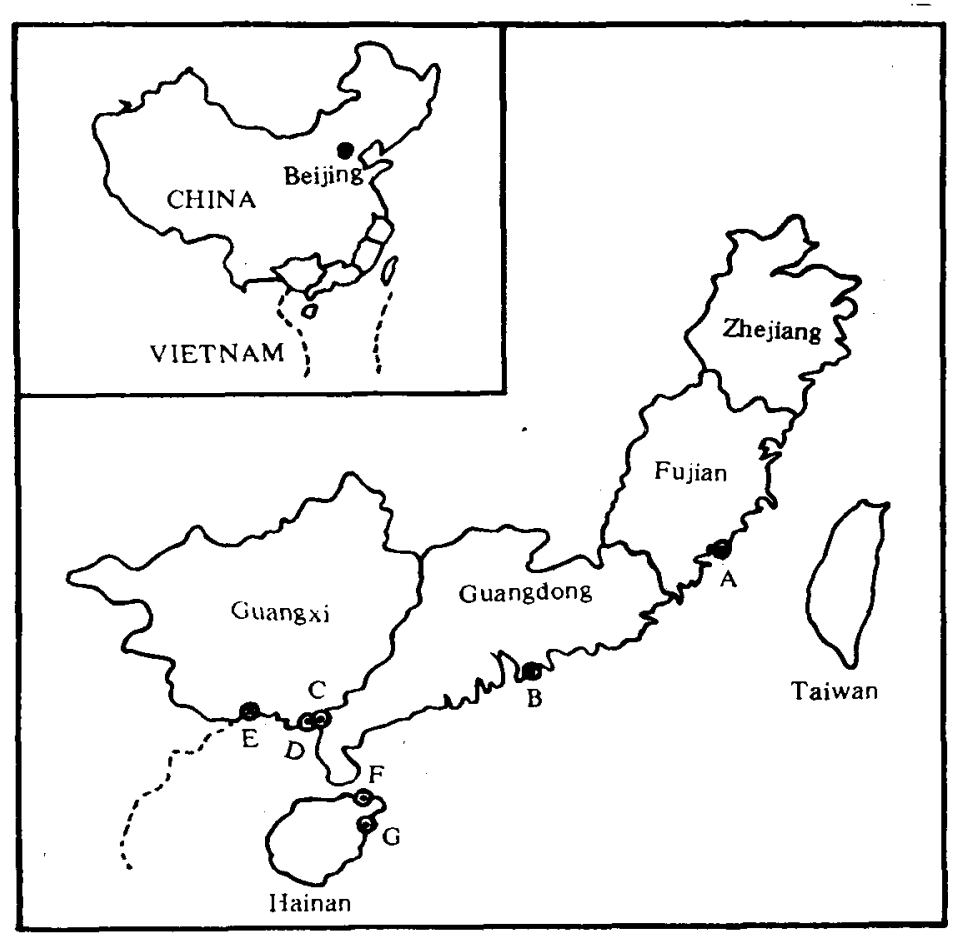

Fig. 1 Distribution of mangrove forests and mangrove nature reserves along coastal provinces in southeast China.

Seabund and mangroves banding together are widely used to protect the coast from erosion in China. The seabund is usually made of rock and mudsoil, sometimes of stems and branches of mangrove trees. During typhoon season, the dangerous seabund needs repaired or enhanced to resist sea waves. For convenient transportation of rock, the landward mangrove trees, such as Bruguiera gymnorrhiza, are cut to form an artificial water way parallel to the bund, so that the boat can anchor everywhere along the bund. This is a major cause for the decline of luxuriant $B$. gymnorrhiza forests in China.

The local Chinese people used to gather timber, firewood, green manure from mangroves, but nowadays there is not enough large mangrove trees available for timber, and chemical fertilizer takes the place of mangrove green manure, such as the nitrogen-rich leaves of Avicennia marina. Cutting of mangroves for firewood is not common at the present, but for comprehensive utilization. Frequently, the removed trees usually grew along the waterway with more barnacles and oysters on their stems and branches. These trees are first thrown into crab pond where, the fouling macrofauna are fed off by crabs, Scylla serrata for instance. After then, the immersed trees are put out of the pond to be dried for firewood. Generally, mangrove plant is not good firewood because of a lot of tannin that will produce heavy smoke during burning. This immersion processing not only supplies feed for mariculture, but also makes better firewood by leaching tannin. However, this kind of use doubtlessly accelerates the degradation of mangrove forests.

In the past time, the long propagules of Kandelia candel were occasionally eaten - 52 •. 
during the year of great famine in Fujian province. Eating Nypa fruticans is peculiar to Hainan Island. The fruits of Avicennia marina is for routine dishes especially in Guangxi province where the pretreated fruits can be found on many vegetable markets from July to October. This collection of fruits breaks the twigs, and shorten the community. Walking within forest destroys a great number of seedlings and young trees, resulting in sparsity of species in the community.

The crab of Scylla serrata, the worms of Sipunculus nudus, Phascolosoma esculen$t a$, and the fishes of Periophthalmus cantonensis, Boleaphthalmus chinensis have a high commercial value in China, which are abundant in mangrove areas. Many mangrove mudflats were completely re-dug once a month. The activity of diggers for these animals usually damages the roots and proves fatal to seedlings and adult trees.

In China, farmers often raise poultry and livestock in mangrove area. Duck and goose go around the forest to search for benthos. Cattle and sheep generally act along the inland mangrove forests to feed on the leaves or young twigs of Avicennia marina and Kandelia candel. Their movement on mudflat frequently buries the artificially planted seedlings, consequently hinders the rehabilitation of the forest.

Traditional use of mangrove plants of Acrostichum aureum, Acanthus ilicifolius, Bruguira exangula, etc. as medicine has a long history, but a few mangroves has been removed on this purpose. Some possible medicinal uses of mangrove plants are expected to be discovered in the future for cancer, AIDS in particular.

Damage to the mangrove system may be caused indirectly and originate in distant areas. Since several years ago, more and more large factories and harbours have been set up along the coastal area. The drainage of polluted water will destroy the wildlife of mangrove ecosystem. The noise of tourists and boats expels the birds such as egret. In estuarine area, the loss of land soil has made some mudflats too hard for Rhizophora stylosa prop roots to grow, and led to the death of the tree.

\section{Rehabilitation action}

The rapid degradation and impasse of mangroves have received a great attention of government decision makers. From 1980 to 1990 , seven mangrove nature reserves were set up in Jiulongjiang (Fujian province), Futian (Guangdong), Zhanjiang (Guangdong), Shankou (Guangxi), Beilun (Guangxi), Dongzhai (Hainan) and Touwan (Hainan). About $46 \%$ of the total mangrove forests, i. e. 6781 ha, are under protection in China. The location and some information about these reserves are showed in Figure 1 and Table 4. Reserves of Shankou and Beilun are under the control of local and central oceanic administration, other five under the control of forestry administration. In these reserves, scientific research, plantation, introduction of new species and public education are conducted. In 1991, the unique institute specialized in mangrove ecosystem studies in China, Guangxi Mangrove Research Center (GMRC), was set up in Beihai city of Guangxi (Fan, 1992), and published papers in a special issue of the Journal of the Guangxi Academy of Sciences. In 1992, The National Academic Commission for Mangrove Ecological Research was established. On November 15 19, 1993, the First Chinese Symposium on Mangrove Ecosystems was held in Beihai of Guangxi. Approximately 90 participants including researchers, managers' and officials attended the sympo- 
sium. Today, an influential program named the Actions of Mangrove Biodiversity Conservation in China is under the consideration of the governmental agencies.

Table 4 Mangrove nature reserves in China.

\begin{tabular}{l|l|l|l|l|l|l|l}
\hline \multicolumn{1}{c|}{ Order) } & \multicolumn{1}{c|}{$\mathrm{A}$} & \multicolumn{1}{c|}{$\mathrm{B}$} & \multicolumn{1}{c|}{$\mathrm{C}$} & $\mathrm{D}$ & \multicolumn{1}{c|}{$\mathrm{E}$} & \multicolumn{1}{c|}{$\mathrm{F}$} & \multicolumn{1}{c}{$\mathrm{G}$} \\
\hline $\begin{array}{l}\text { Name of } \\
\text { reserve }\end{array}$ & $\begin{array}{l}\text { Jiulong- } \\
\text { jiang }\end{array}$ & Futian & Zhanjiang & Shankớn & Beilun & Dongzhai & Touwan \\
\hline $\begin{array}{l}\text { Situated } \\
\text { province }\end{array}$ & Fujian & Guangdong & Guangdong & Guangxi & Guangxi & Hainan & Hainan \\
\hline $\begin{array}{l}\text { Location } \\
114^{\circ} 29^{\prime} \mathrm{N}\end{array}$ & $\begin{array}{l}22^{\circ} 35^{\prime} \mathrm{N} \\
114^{\circ} 05^{\prime} \mathrm{E}\end{array}$ & $\begin{array}{l}21^{\circ} 29^{\prime} \mathrm{N} \\
109^{\circ} 44^{\prime} \mathrm{E}\end{array}$ & $\begin{array}{l}21^{\circ} 28^{\prime} \mathrm{N} \\
109^{\circ} 43 \mathrm{E}^{\prime}\end{array}$ & $\begin{array}{l}21^{\circ} 30^{\prime} \mathrm{N} \\
108^{\circ} 09^{\prime} \mathrm{E}\end{array}$ & $\begin{array}{l}19^{\circ} 54^{\prime} \mathrm{N} \\
110^{\circ} 20^{\prime} \mathrm{E}\end{array}$ & $\begin{array}{l}19^{\circ} 34^{\prime} \mathrm{N} \\
110^{\circ} 45^{\prime} \mathrm{E}\end{array}$ \\
\hline $\begin{array}{l}\text { Setting } \\
\text { time }\end{array}$ & 1988 & 1984 & 1990 & 1990 & 1990 & 1980 & 1981 \\
\hline $\begin{array}{l}\text { Protected } \\
\text { area (ha) }\end{array}$ & 200 & 405 & 2000 & 8000 & 2680 & 5200 & 3333 \\
\hline $\begin{array}{l}\text { Mangrove } \\
\text { area (ha) }\end{array}$ & 67 & 111 & 933 & 730 & 1027 & 1733 & 2000 \\
\hline $\begin{array}{l}\text { No. of mang- } \\
\text { rove species }\end{array}$ & 4 & 7 & 12 & 12 & 11 & 20 & 26 \\
\hline $\begin{array}{l}\text { Sponsor of } \\
\text { government }\end{array}$ & local & central & local & central & local & central & local \\
\hline
\end{tabular}

a) The locations of reserves form $A$ to $G$ are shown in Figure 1 .

b) The species include mangrove and semi-mangrove plants.

REFERENCES
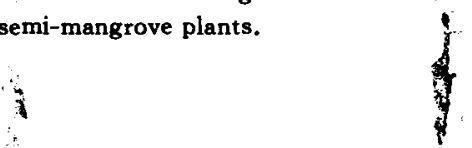

Chen S P, et al. , 1986. Mangrove and its reservation in Hainan Island. Ecologic Science, 1:12 19 (in Chinese)

Fan H Q, 1990. Ecological economy value of mangrove forest, its crisis and countermeasures. Nature Resources, 4:55 58 (in Chinese)

Fan H Q, 1992. Guangxi Mangrove Research Center. ISME Newsletter, 7:2

Fan H Q, 1993. A proposal for the international cooperation of mangrove ecosystem studies in Guangxi of China. Journal of the Guangxi Academy of Sciences; special issue for mangrove theses, $9(2): 98$ $\sim 103$, (in Chinese)

Lin P, Wei X M, 1981. The ecological studies of subtropical mangroves in Fujian, China. Acta Phytoecological et Geobotanica Sinica, 5(3): $177 \sim 186$ (in Chinese)

Lin $\mathrm{P}, \mathrm{Lu}$ C Y, 1985. The mangrove forest distributed around the coast of Hainan island. J. Xiamen University (Nature Science), 24(1):116 127 (in Chinese)

Lin $P$, Fan H Q, 1992. Development of the natural reservations of mangroves along China coast. $U N-$ ESCO Technical'Papers in Marine Science 64-Coastal Systems Studies and Ustainable Development, Paris, UNESCO, 90 98

Lin $P, 1993$. Distribution of species and the physiognomic classification on mangrove forests in China. Li, Z J (ed. 2:-Transactions of Environmental Science and Ecology, Xiamen: Press of Xiamen Universion, 74 79, (in Chinese)

Su S G, 1989. The mangrove resource along China coast. International Conference on Mangroves, Okinawa, Japan, UNESCO. $57 \sim 58$ 